\title{
Associations between State Level Policy and AIDS among Men Who Have Sex with Men
}

\author{
Kyle W Jones ${ }^{1,2 *}$, Alicia K Matthews ${ }^{1,2}$, Chien-Ching $\mathrm{Li}^{3}$, Zachary Dembo ${ }^{2}$ and Maria Vargas ${ }^{1}$ \\ ${ }^{1}$ University of Illinois at Chicago, USA \\ ${ }^{2}$ Howard Brown Health Center, USA \\ ${ }^{3}$ Rush University, USA
}

\begin{abstract}
Objective: There continues to be a large disparity in the prevalence of HIVIAIDS among men who have sex with men (MSM) compared to all other populations. Recent research suggests discriminatory laws may play a role in the health outcomes of the LGBT community. We hypothesized that discriminatory state-level relationship recognition, employment, and housing policies would predict a higher proportion of MSM among the population living with AIDS than heterosexuals while controlling for state-level healthcare quality and political orientation.
\end{abstract}

Method: Data for the proportion of AIDS cases comprised of MSM and heterosexuals were collected for 2008 for each state from CDC 2010 State Surveillance Reports. Additionally, relationship recognition, housing discrimination, and employment discrimination laws were collected from 2008 for each state. Covariates included the political orientation of each state based on the 2008 presidential election and a composite measure of overall healthcare quality of each state created by the Agency for Healthcare Research and Quality.

Results: Overall, MSM account for the highest proportion of people living with AIDS in the US. Hierarchical regressions indicated that MSM accounted for a higher proportion of people living with AIDS in states with discriminatory relationship recognition policies. Housing discrimination policies, employment discrimination policies, healthcare quality, and political orientation were not associated with the proportion of MSM or heterosexuals that comprise the total population of people living with AIDS in each state.

Conclusion: Findings suggest relationship recognitions are a unique protective factor against HIV/AIDS for MSM. Future research is needed to fully understand the mechanisms by which relationship recognitions serve as a protective factor from HIVIAIDS for MSM.

Keywords: AIDS; HIV; MSM; Public policy; Relationship recognitions; Discrimination

\section{Introduction}

Men who have sex with men (MSM) continue to have the highest HIV and AIDS rates of any other group [1,2]. In the United States (US), MSM constitute approximately $2 \%$ of the population; however, $63 \%$ of all new HIV infections were among MSM in 2010. Additionally, approximately $56 \%$ of all HIV-infected individuals in the US are MSM as of 2010. More troubling, HIV and AIDS rates have been on the rise in MSM for the past several years [1]. While the effect of individual level discrimination (eg. experience of violence, stigma, and homophobia) on risky health behaviors associated with HIV-infection is wellknown, less is known about the effects public policies may have on the prevalence of risky health behaviors on a population level [3-6].

Recent research suggests public policy is a unique factor when assessing health among the LGBT community [7-9]. For example, institutional discrimination confers increased risk for psychiatric disorders among the LGBT community [7,10-12]. Moreover, after Massachusetts legalized gay marriage, hospital utilization, psychiatric visits, and overall healthcare expenditures among gay men was significantly reduced [13]. Other studies suggest that environments with policies that support the LGBT community endorse lower suicide and substance use rates among LGBT youth compared to less supportive environments $[9,14]$. While there is evidence that public policy has an effect on the health of LGBT individuals, it is unclear whether LGBT specific public policy affects HIV and AIDS rates among MSM.

The current study is a preliminary analysis of the effect of statelevel institutional LGBT discrimination on the proportion of MSM that comprise the total population of people living with AIDS in each state compared to heterosexuals. We looked at state-level proportions of MSM and heterosexuals that have AIDS as reported by the Centers for Disease Control and Prevention in 2008 [15] and 3 areas of state-level legislation as of 2008: (1) gay marriage recognitions, (2) employment discrimination protections, (3) and housing discrimination protections. Data from 2008 was used because that is the latest data available for state-level proportions of MSM and heterosexuals that have AIDS. We hypothesized that state level LGBT discriminatory policies would predict a higher proportion of MSM among the population living with AIDS than heterosexuals while controlling for healthcare quality and political orientation.

\section{Methods}

All data for state-level proportions of AIDS in 2008 was collected from the individual state profiles of the National Center of HIV/AIDS, Viral Hepatitis, STD, and TB Prevention of the CDC [15]. The current study uses proportions of people living with AIDS for men who have sex with men (MSM), intravenous drug using MSM, heterosexuals,

*Corresponding author: Kyle W Jones, Department of Psychology, University of Illinois at Chicago 1007 W. Harrison St. (M/C) 285 Chicago, IL 60607, USA, Tel: 916201-0921; Fax: (312) 413-4122; E-mail: kjones42@uic.edu

Received June 20, 2014; Accepted September 19, 2014; Published September 27,2014

Citation: Jones KW, Matthews AK, Li CC, Dembo Z, Vargas M (2014) Associations between State Level Policy and AIDS among Men Who Have Sex with Men. J AIDS Clin Res 5: 353. doi:10.4172/2155-6113.1000353

Copyright: @ 2014 Jones KW, et al. This is an open-access article distributed unde the terms of the Creative Commons Attribution License, which permits unrestricted use, distribution, and reproduction in any medium, provided the original author and source are credited. 
and intravenous drug using heterosexuals from all 50 states. As we are assessing for AIDS proportions that are associated with discriminatory policies regardless of method of transmission, MSM and intravenous drug using MSM were combined into a single category. This was also done for the heterosexual AIDS proportions. These proportions were straight percentages of the number of AIDS cases for each state.

\section{State-level legislation}

We used 3 areas of state-level LGBT legislation: (1) relationship recognitions (i.e., civil unions, domestic partnerships, or marriage), (2) employment discrimination protections, and (3) housing discrimination protections. For each of these three categories, we created a binary variable that indicated the absence or presence of these protections. States with laws allowing gay marriage, civil unions, or domestic partnerships were coded as 1 . States that have any laws protecting against discrimination in employment in both the private and public sectors and housing were coded as 1 in both of those variables. All variables were coded using legislation specific to 2008 according to the Human Rights Campaign [16-21] and the Center for American Progress Action Fund [22].

\section{Healthcare quality}

We acknowledge that the overall healthcare quality of a given state might affect AIDS rates (i.e., poor HIV management will increase the likelihood of progression to full blown AIDS diagnosis) [23,24]. Healthcare quality will be used as a control variable. We used a composite variable developed in 2008 by the U.S. Agency for Healthcare Research and Quality (AHRQ) to assess the overall quality of healthcare in each individual state [25]. The Health Care Quality Index score is a continuous variable ranging from 0 (poor healthcare quality compared to other states on healthcare indicators assessed by AHRQ) to 100 (better healthcare quality compared to other states on healthcare indicators assessed by AHRQ). Healthcare indicators assessed by AHRQ include overall healthcare quality, care provided for 5 key clinical conditions (cancer, diabetes, heart disease, respiratory disease, and maternal and child health), settings of care (hospitals, ambulatory care, and nursing homes), and type of care (preventive, acute, and chronic).

\section{Political orientation}

Political orientation of a state could have a direct effect on the minority stress experienced by its LGBT population [26]. We coded states using a binary variable as liberal vs. conservative based on that state's vote in the 2008 presidential election. We included this variable as a covariate to determine the effect of the politics of a state.

\section{Statistical analysis}

We described the percentages of MSM and heterosexuals that comprise the total population of people living with AIDS using simple non-parametric descriptives. We used hierarchical linear regression analyses to assess the effect of state-level legislation on AIDS proportions among the 2 groups. Specifically, healthcare quality and political orientation were entered in the first step of the analyses as control variables in the analyses. Then relationship recognitions, employment protections, and housing protections were entered as predictor variables in the second step. All proportions were logittransformed to make them normally distributed to use in hierarchical linear regression analyses [27,28]. All analyses were performed using SPSS 22.0 [29].

\section{Results}

All 50 states were included in these analyses. Fourteen states had

\begin{tabular}{|l|c|c|c|c|c|c|c|c|c|c|}
\hline \multirow{2}{*}{$\begin{array}{l}\text { Mode of } \\
\text { Infection }\end{array}$} & \multicolumn{2}{|c|}{$\begin{array}{c}\text { Relationship } \\
\text { Recognitions }\end{array}$} & \multicolumn{2}{c|}{ Housing } & \multicolumn{2}{c|}{ Employment } & \multicolumn{2}{c|}{$\begin{array}{c}\text { Healthcare } \\
\text { Quality }\end{array}$} & \multicolumn{2}{|c|}{$\begin{array}{c}\text { Political } \\
\text { Orientation }\end{array}$} \\
\cline { 2 - 11 } & $\mathrm{B}$ & $\mathrm{p}$ & $\mathrm{B}$ & $\mathrm{p}$ & $\mathrm{B}$ & $\mathrm{p}$ & $\mathrm{B}$ & $\mathrm{p}$ & $\mathrm{B}$ & $\mathrm{p}$ \\
\hline MSM & -0.70 & $0.03^{*}$ & 0.06 & 0.84 & 0.60 & 0.18 & 0.00 & 0.72 & -0.32 & 0.25 \\
\hline Hetero & 0.67 & $0.04^{*}$ & -0.14 & 0.66 & -0.54 & 0.24 & 0.00 & 0.93 & 0.38 & 0.19 \\
\hline
\end{tabular}

*Significant at the $p<0.05$ level

Table 1: Effect of LGBT policies on AIDS proportions.

relationship recognitions while 21 states had LGB/T employment protections and 13 states had LGB/T housing protections. MSM represent a higher proportion of people living with AIDS than heterosexuals (MSM Median $=65.00 \%, Q 1=52.90 \%$, Q3=72.63\%; Heterosexual Median=31.05\%, Q1=24.38\%, Q3=42.03\%).

\section{The effect of LGBT policies}

LGBT relationship recognitions predicted a lower proportion of MSM among people living with AIDS (Table 1). Consistent with this, LGBT relationship recognitions predicted a higher proportion of heterosexuals among people living with AIDS. LGBT employment protections, LGBT housing protections, healthcare quality, and state political orientation were not predictive of percentage of AIDS cases for either group.

\section{Discussion}

The finding that same-sex relationship recognitions are associated with a reduction in the proportion of MSM that comprise the population living with AIDS is consistent with other studies suggesting a reduction in other morbidities and hospital visits when same-sex relationship recognitions are instituted [13]. Advocacy to increase relationship recognitions may reduce the prevalence of HIV/AIDS among MSM. The validation of same-sex relationships may symbolize increased acceptance compared to anti-discrimination laws that focus on the need for protection.

In future studies, we can assess the longitudinal effects these policies have on the proportion of people living with AIDS using data from all the years subsequent to 2008 using a more extensive repeated measures analysis. Other factors that could affect the prevalence of HIV/AIDS that the current study did not take into account are the racial makeup of states, incomes, and the percentage of individuals that have health insurance. These factors are more appropriately included in a more powerful longitudinal study assessing the effects of LGBT policies on AIDS proportions over time.

Future research should assess the effects of interactions of LGBT policies, mean incomes, state racial makeup, and the proportion of MSM that have health insurance on their HIV/AIDS rates in a longitudinal analysis. Additional research is needed on macro level policies that could affect the health outcomes in general in the entire LGBT population. More extensive longitudinal analyses of the protective benefits of macro-level protections on the physical and mental health behaviors LGBT populations are needed.

\section{References}

1. CDC (2011) HIVIAIDS Surveillance Report, 2010 (Rev edn), US Department of Health and Human Services, Centers for Disease Control and Prevention.

2. CDC (2007) HIVIAIDS Surveillance Report, 2005. (Rev edn), US Department of Health and Human Services, Centers for Disease Control and Prevention.

3. Hughes TL, Eliason M (2002) Substance use and abuse in lesbian, gay, bisexual and transgender populations. Journal of Primary Prevention 22: 263298.

4. McCabe SE, Bostwick WB, Hughes TL, West BT, Boyd CJ (2010) The 
Citation: Jones KW, Matthews AK, Li CC, Dembo Z, Vargas M (2014) Associations between State Level Policy and AIDS among Men Who Have Sex with Men. J AIDS Clin Res 5: 353. doi:10.4172/2155-6113.1000353

Page 3 of 3

relationship between discrimination and substance use disorders among lesbian, gay, and bisexual adults in the United States. Am J Public Health 100: 1946-1952.

5. Wilson PA, Yoshikawa $H$ (2004) Experiences of and responses to social discrimination among Asian and Pacific Islander gay men: their relationship to HIV risk. AIDS Educ Prev 16: 68-83.

6. Wong CY, Tang CS (2004) Sexual practices and psychosocial correlates of current condom use among Chinese gay men in Hong Kong. Arch Sex Behav 33: $159-167$.

7. Hatzenbuehler ML (2009) How does sexual minority stigma "get under the skin"? A psychological mediation framework. Psychol Bull 135: 707-730.

8. Hatzenbuehler ML, Nolen-Hoeksema S, Dovidio J (2009) How does stigma "get under the skin"?: the mediating role of emotion regulation. Psychol Sci 20: $1282-1289$.

9. Hatzenbuehler ML (2011) The social environment and suicide attempts in lesbian, gay, and bisexual youth. Pediatrics 127: 896-903.

10. Hatzenbuehler ML, Keyes KM, Hasin DS (2009) State-level policies and psychiatric morbidity in lesbian, gay, and bisexual populations. Am J Public Health 99: 2275-2281.

11. Maisel NC, Fingerhut AW (2011) California's ban on same-sex marriage: The campaign and its effects on gay, lesbian, and bisexual individuals. Journal of Social Issues 67: 242-263.

12. Hatzenbuehler ML, McLaughlin KA, Keyes KM, Hasin DS (2010) The impact of institutional discrimination on psychiatric disorders in lesbian, gay, and bisexual populations: a prospective study. Am J Public Health 100: 452-459.

13. Hatzenbuehler ML, O'Cleirigh C, Grasso C, Mayer K, Safren S, et al. (2012) Effect of same-sex marriage laws on health care use and expenditures in sexual minority men: a quasi-natural experiment. Am J Public Health 102: 285-291.

14. Hatzenbuehler ML, Pachankis JE, Wolff $J(2012)$ Religious climate and health risk behaviors in sexual minority youths: a population-based study. Am J Public Health 102: 657-663.

15. CDC (2010) National Center of HIVIAIDS, viral hepatitis, STD, and TB prevention state profiles. CDC, Atalanta, GA.
16. Human Rights Campaign (2004) Equality from state to state. (1st edn), Human Rights Campaign Foundation, Washington, D.C.

17. Human Rights Campaign (2005) Equality from state to state. (1st edn), Human Rights Campaign Foundation, Washington, D.C.

18. Human Rights Campaign (2006) Equality from state to state. (1st edn), Human Rights Campaign Foundation, Washington, D.C.

19. Human Rights Campaign (2007) Equality from state to state. (1st edn), Human Rights Campaign Foundation, Washington, D.C.

20. Human Rights Campaign (2008) Equality from state to state. (1st edn), Human Rights Campaign Foundation, Washington, D.C.

21. Human Rights Campaign (2009) Equality from state to state. (1st edn) Human Rights AIDS, state-level policies, \& MSM 11 Campaign Foundation, Washington, D.C.

22. Center for American Progress Action Fund (2012) A state-by-state examination of nondiscrimination laws and policies (1st edn), Center for American Progress Action Fund, Washington, D.C.

23. Adimora AA, Ramirez C, Schoenbach VJ, Cohen MS (2014) Policies and politics that promote HIV infection in the Southern United States. AIDS 28 1393-1397.

24. Schuster MA, McGlynn EA, Brook RH (2005) How good is the quality of health care in the United States? 1998. Milbank Q 83: 843-895.

25. Agency for Healthcare Research and Quality (2008) National healthcare quality report. Agency for Healthcare Research and Quality, Rockville, MD.

26. Hatzenbuehler ML, Bellatorre A, Lee Y, Finch BK, Muennig P, et al. (2014) Structural stigma and all-cause mortality in sexual minority populations. Soc Sci Med 103: 33-41.

27. Barr DJ (2008) Analyzing "visual world" eyetracking data using multileve logistic regression. Journal of Memory and Language 59: 457-474.

28. Fine $A B$, Florian Jaeger $T$ (2013) Evidence for implicit learning in syntactic comprehension. Cogn Sci 37: 578-591.

29. IBM Corp (2013) IBM SPSS Statistics for Mac, Version 22.0. IMB Corp Armonk, NY. 